\title{
Sphingosine 1-Phosphate Receptor 1
}

National Cancer Institute

\section{Source}

National Cancer Institute. Sphingosine 1-Phosphate Receptor 1. NCI Thesaurus. Code C102500.

Sphing osine 1-phosphate receptor 1 (382 aa, $\sim 43 \mathrm{kDa}$ ) is encoded by the human S1PR1 gene. This protein plays a role in phospholipid binding. 